\title{
POTENSI RISIKO PEMBIAYAAN MUDHARABAH DI BANK SYARI'AH: SEBUAH TINJAUAN PADA HUBUNGAN KEAGENAN
}

\author{
Aswin \\ IAIN Syaikh Abdurrahman Siddik Bangka Belitung \\ sulisagustina01@gmail.com
}

\begin{abstract}
Financing is the main task of Islamic banks, especially the provision of facilities for providing funds to solve community problems financially. One of the financing products that is the core product of Islamic banks is mudharabah financing. In practice, financing using mudharabah contracts is minimal, this is inseparable from the large potential risks faced by Islamic banking, one of the risks arising from mudharabah financing is a conflict of interest between the shahib maal/principal and mudharib/agent.
\end{abstract}

Keywords : Islamic Bank, mudharabah, risk, agency.

\begin{abstract}
Abstrak
Pembiayaan merupakan tugas pokok bank syariah, khususnya pemberian fasilitas pendanaan untuk mengatasi masalah masyarakat secara finansial. Salah satu produk pembiayaan yang menjadi core product dari bank syariah yaitu pembiayaan mudharabah. Pada prakteknya pembiayaan dengan menggunakan akad mudharabah sangat minim dilakukan, hal tersebut tidak terlepas dari besarnya potensi risiko terutama bagi pihak bank syariah, salah satu risiko yang timbul dari pembiayaan mudharabah adalah adanya konflik kepentingan antara shahib maal/principal dan mudharib/agent.
\end{abstract}

Kata kunci : Bank syariah, mudharabah, risiko, keagenan. 


\section{A. Pendahuluan}

Sejak diundangkannya UU Nomor 10 Tahun 1998 tentang Perubahan UU Nomor 7 Tahun 1992 (UU Perbankan), industri perbankan Indonesia telah menerapakan dual banking system yaitu sistem perbankan konvensional dengan perangkat suku bunga (disebut sebagai perbankan konvensional), dan sistem perbankan yang tunduk pada prinsip-prinsip Syariah Islam (dikenal sebagai perbankan syariah). ${ }^{1}$

Seiring berjalannya waktu, bank syari'ah mengalami perkembangan itu dapat dilihat adanya bank konvensional membuka unit syari'ah sebagai wujud dual banking system. Diundangkannya UU Nomor 21 Tahun 2008 tentang Bank Syari'ah menjadi legal basis lembaga intermediasi dengan menggunakan prinsip syari'ah. Selain itu, keberadaan bank syariah merupakan jawaban untuk memenuhi kebutuhan aktual masyarakat, terutama umat Islam, dalam menjalankan kegiatan komersial melalui perantara tanpa perilaku riba².

Kristalisasi nilai-nilai religius yang terkandung dalam undangundang tersebut membawa konsekuensi logis bagi penerapan hal-hal yang dilarang agama atau semua hal yang diharamkan untuk dilakukan dalam kegiatan usaha yang berbentuk produk-produk syari'ah. hal dimaksud berbeda dengan system perbankan konvensional melakukan fungsi intermediasi keuangannya menggunakan prinsip bunga (interest) yang menurut pandangan syari'ah dipersamakan dengan riba. Bunga (riba) dipergunakan oleh bank-bank konvensional sebagai suatu cara untuk mendorong masyarakat berinvestasi/menyimpan uang dalam bentuk tabungan, sehingga dapat dikatakan bahwa operasional system perbankan tidak mungkin berjalan dan berkembang tanpa mengandalkan

\footnotetext{
${ }^{1}$ Undang-undang No. 10 Tahun 1998 Pasal 1 Angka 3, Himpunan Undang-undang Perbankan Republik Indonesia, (Jakarta: Asa Mandiri, 2008), 65.

${ }^{2}$ Evita Isretno, Pembiayaan Mudharabah Dalam Sistem Perbankan Syari'ah, (Jakarta: Cintya Press, 2011). Hal 3
} 
bunga bank. Padahal bunga dalam pandangan pakar ekonomi syari'ah, memiliki efek inflasi yang disebabkan oleh suku bunga sebagai biaya uang.

Dalam kapasitas bank sebagai perantara antara investor dan penerima pinjaman, bank harus mengumpulkan dana dari investor yang nantinya akan disalurkan kepada masyarakat. Alasan diadakannya penghimpunan dana adalah untuk memperluas permodalan, sehingga nantinya dapat menopang kapasitas bank sebagai media perantara.

Pembiayaan adalah salah satu usaha utama bank, khususnya menyediakan dana untuk mengatasi masalah masyarakat secara finansial. Oleh karenanya, perbankan syariah memberikan pembiayaan berpijak pada standar pembiayaan syariah yang fundamental. Pertama, standar ekuitas, bahwa pembiayaan umumnya menguntungkan baik pihak yang menggunakan aset maupun pihak yang memberikan aset. Kedua, Prinsip kepercayaan, adalah premis dalam memutuskan dukungan pembiayaan seperti halnya dalam menghitung pendapatan bersih dan pembagian keuntungan yang menyertai pembiayaan. ${ }^{3}$

\section{B. Pembahasan}

\section{Bank Syari'ah}

Bank Syari'ah adalah bank berbasis bagi hasil, dan bank yang prosedur operasionalnya berdasarkan pada Al-Qur'an dan Hadits. Disamping itu bank syariah merupakan lembaga keuangan yang kegiatan utamanya adalah menghimpun dana dan menyediakan pembiayaan dan jasa-jasa keuangan lainnya dengan prinsip syari'at Islam.

\section{Hlm. 16}

${ }^{3}$ Muhammad, Manajemen Pembiayaan Bank Syari'ah ( Yogyakarta: UPN AMP YKPN, 2005), 
Sutan Remy Shahdeiny mendefinisikan bank syariah yaitu lembaga yang bertindak selaku perantara dengan menggalang dana dari masyarakat dan menyalurkan kepada masyarakat berdasarkan prinsip hukum Islam.

Sebagai lembaga keuangan, bank syariah memiliki mekanisme dasar, yaitu mendapatkan dana dari masyarakat/investor dam berkewajiban menyalurkan kepada orang lain dengan prinsip hukum Islam.

\section{Karakteristik Pembiayaan}

Dalam kontrak bisnis islam, tingkat kepastian hasil (return) dari kontrak bisnis yang dilakukan pada dasarnya terbagi menjadi dua kelompok besar ${ }^{4}$, yaitu:

a. Natural Certainty Contrak,

Suatu akad dalam suatu usaha dapat memberikan kepastian pembayaran. Contoh dalam akad ini adalah akad jual beli (ba'i) dan akad sewa (ijarah).

b. Natural Uncertainty Contrak.

Kontrak bisnis atau kontrak dimana pembayaran atau pendapatan tidak pasti, baik jumlah pembayaran maupun waktu pembayarannya. Tingkat pengembalian dari jenis kontrak ini bisa positif atau bahkan negatif. Contoh akad ini seperti mudharabah dan musyarakah.

\section{Definisi Pembiayaan Mudharabah}

Al-Mudharabah merupakan asal kata dari dharb, artinya memukul. Dapat pula diartikan seseorang mengerahkan tenaga mengelola usaha. Dalam fiqih mualamah, beberapa ulama Mazhab

\footnotetext{
${ }^{4}$ Adiwarman A. Karim Bank Islam: Analisis Fiqh dan Keuangan, PT. Raja Grafindo Persada Jakarta, 2008, hal. 43.
} 
mendefinisikan terminology mudharabah dengan berbagai macam. ${ }^{5}$ Diantaranya adalah Mazhab Hanafi mendifinisikan mudharabah adalah kesepakatan bagi hasil dengan modal satu pihak dan usaha (usaha) pihak lain. Mazhab Maliki menamai mudharabah sebagai, penyerahan uang di muka oleh pemilik modal dalam jumlah yang ditentukan kepada orang lain untuk menjalankan bisnis dengan imbalan bagi hasil. Mazhab Syafi'i mendifinisikan mudharabah yaitu investor menyerahkan beberapa dana kepada orang buat usaha adapun keuntungannya dibagi antara keduanya. Mazhab hambali mendifinisikan mudharabah selaku penyerahan sesuatu benda ataupun sejenisnya dalam jumlah yang jelas kepada orang untuk usaha dengan memperoleh keuntungan.

Adiwarman Karim mendefiniskan akad mudharabah sebagai suatu bentuk akad yang salah satu pihak bertindak sebagai pemilik dana menitipkan sejumlah modal yang dikelola pihak kedua dengan tujuan menghasilkan keuntungan. ${ }^{6}$

Peraturan Bank Indonesia (BI) Nomor: 9/19/PBI/2007 Pasal 3 menyatakan "mudharabah ialah penyediaan dana dari bank kepada pengelola dana untuk suatu bisnis sesuai prinsip hukum islam, adapun keuntungan usaha dibagi antara kedua belah pihak bersumber pada konvensi. ${ }^{7}$

Fatwa DSN Nomor. 07/DSN-MUI/IV/2000 tentang ketentuan aplikasi penyaluran dana mudharabah :

a. Ketentuan Penyaluran Dana

\footnotetext{
${ }^{5}$ Berbagai pendapat ulama ini disarikan dari tulisan Muhammad, Kontruksi Mudharabah dalam Bisnis Syari'ah, Yogyakarta: BPEE, 2005, Edisi 1, Hal. 51.

${ }^{6}$ Adiwarman A. Karim, Bank Islam - Analisis Fikih dan Keuangan, Edisi ketiga, (Jakarta: PT. Raja Grafindo Persada, 2007), hal. 30.

7 Evita Isretno, Pembiayaan Mudharabah Dalam Sistem Perbankan Syari'ah, Jakarta: Cintya Press, 2011, hlm. 21.
} 
Potensi Risiko Pembiayaan Mudharabah ...

1) Mudharabah merupakan penyediaan dana oleh bank kepada pihak lain buat suatu usaha.

2) Waktu usaha, serta profit ditetapkan bersumber pada konvensi kedua pihak.

3) Pengelola bisa melaksanakan usaha sesuai kesepakatan serta cocok dengan prinsip islam; serta bank tidak turut dan dalam manajemen industri ataupun proyek namun memiliki hak buat melaksanakan pembinaan serta pengawasan.

4) Banyaknya dana harus dinyatakan, dan dalam bentuk tunai dan bukan piutang.

5) Standar usaha, prosedur pendanaan, mekanisme bagi hasil diatur oleh bank dengan mempertimbangkan fatwa DSN.

6) Biaya operasional ditanggung mudharib.

7) Jika pemberi dana melanggar kontrak, mudharib berhak atas segala kompensasi.

\section{Dasar Hukum Pembiayaan Mudharabah}

Sumber hukum akad mudharabah dalam Alquran sebagai berikut ${ }^{8}$.

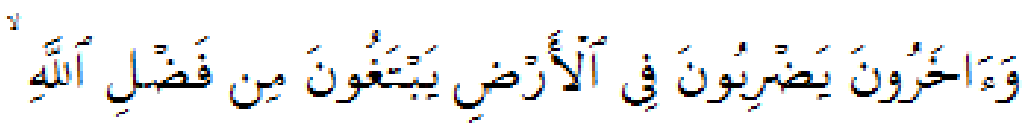

".......dan dari orang-orang yang berjalan di muka bumi mencari sebagian dari karunia Allah AWT...."( QS al Muzzamil Ayat 20).

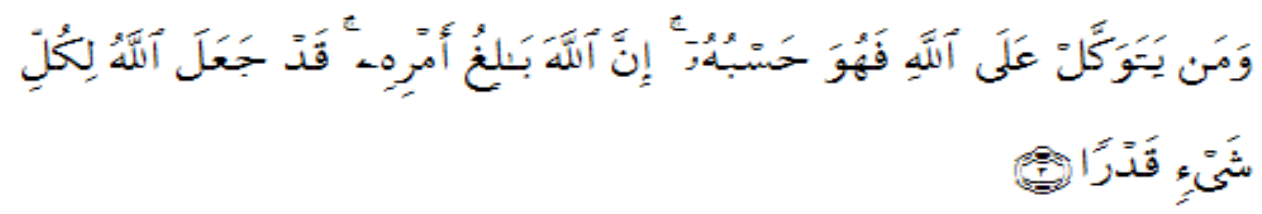

8 Departemen Agama RI, Al-Qur'an dan Terjemahnya, (Jakarta : Yayasan Penyelenggara Penterjemah dan Pentafssir Al-Qur aan, 1979). 
"Dan Barangsiapa yang bertawakkal kepada Allah niscaya Allah akan mencukupkan (keperluan)nya. Sesungguhnya Allah melaksanakan urusan yang (dikehendaki)Nya. Sesungguhnya Allah telah Mengadakan ketentuan bagi tiap-tiap sesuatu". (QS At-Thalaaq ayat 3).

\section{Jenis Pembiayaan Mudharabah}

Secara universal, mudharabah dibagi dalam dua tipe, ialah unrestricted investment dan restricted investment. Adapun unrestricted investment merupakan kontrak berupa kerjasama antara shahibul maal (penyedia dana) dan mudharib (pengelola dana), tidak dibatasi oleh tipe usaha, waktu dan bidang usaha. ${ }^{9}$

Sedangkan restricted investment ialah akad yang batasi jenis usaha, waktu dan lokasi usaha. Oleh karena itu, pada awal akad, telah ditentukan jenis usaha dan cakupan usaha mudharib yang menerima pembiayaan. ${ }^{10}$

\section{Teori Keagenan}

Teori keagenan memberikan pedoman bahwa ada dua pihak dengan kepentingan sendiri-sendiri yaitu principal (pemilik) dan agent (pengelola) perusahaan. Investor memberikan kewenangan kepada agen untuk mengelola kekayaan investor. Dengan harapan memperoleh keuntungan dan dapat meningkatkan kekayaan dan kemakmuran investor. Sehingga terjalin sebuah agency relationship (hubungan keagenan).

Jensen dan Meckling dalam Ahmad Elqorni mengartikan Agency Theory adalah hubungan keagenan dimana satu atau lebih prinsipal menggunakan orang atau agen dalam bentuk kontrak kerja sama menjalankan kegiatan perusahaan. Pada teori ini, prinsipal adalah pemegang saham/pemilik/investor sedangkan agen adalah manajer

${ }^{9}$ Muhammad, Kontruksi Mudharabah Dalam Bisnis Syari'ah, (Mudharabah Dalam Wacana Fiqih Dan Praktik Ekonomi Modern), Yogyakarta: BPEE, 2005, edisi pertama, hal. 43.

${ }^{10}$ Ibid., hal. 43. 
yang menjalankan perusahaan. Prinsipal menyediakan dana dan fasilitas lainnya untuk operasional perusahaan, sedangkan agen berkewajiban menjalankan perusahaan untuk kemakmuran atau keuntungan pemilik perusahaan. ${ }^{11}$

Dalam teori keagenan, manajer adalah pemegang saham dan agen adalah manajemen yang menjalankan perusahaan. Prinsipal memberi wewenang kepada agen untuk melakukan transaksi atas nama prinsipal dan diharapkan membuat keputusan terbaik bagi prinsipal. Persoalannya, sering terjadi perbedaan kepentingan antara kedua belah pihak. Perbedaan tersebut menyebabkan keputusan manajemen yang tidak sesuai dengan kepentingan pemegang saham.

\section{Konflik Keagenan}

Teori keagenan dapat dianggap sebagai model kontrak antara satu atau lebih orang (pihak), satu pihak disebut agent dan pihak yang lain disebut principal. Principal mewakilkan pertanggungjawaban atas pengambilan keputusan kepada agent, dapat juga dikatakan bahwa principal mendelegasikan kepada agent untuk melaksanakan pekerjaan tertentu sesuai dengan kontrak kerja yang telah disepakati. Wewenang agent dan principal diatur dengan kesepakatan bersama dalam kontrak kerja. ${ }^{12}$

Pengelola sebagai pihak yang dipercayakan oleh pemilik atau principal untuk mengelola dana, harus bertanggung jawab atas apa yang dipercayakan kepadanya. Masalah muncul ketika kedua belah pihak memiliki pandangan dan posisi yang berbeda mengenai pemberian informasi yang akan digunakan oleh prinsipal.

\footnotetext{
${ }^{11}$ Ahmad Elqorni, 2009, "Mengenal Teori Keagenan”, Artikel/ringkasan the management lecture resume, http://elqorni.wordpress.com/2009/02/26/. Diakses 05 November 2021.

${ }^{12}$ Amanita Novi Yushita, Earnings Management Dalam Hubungan Keagenan, Jurnal Pendidikan Akuntansi Indonesia Vol. VIII. No. 1 - Tahun 2010, hal. 57.
} 
Agen yang memiliki informasi yang nyata dan lengkap tentang bisnis dan kinerja perusahaan tidak akan memberikan semua informasi yang mereka miliki, sedangkan principal akan meminta agent untuk memberikan informasi yang lengkap. Keinginan principal tersebut pada umumnya sulit dipenuhi, sehingga menimbulkan konflik keagenan. ${ }^{13}$

\section{Penyebab Konflik Keagenan}

Konflik keagenan khususnya konflik antara principal dan agent terjadi karena berbagai sebab. Salah satu aspeknya adalah ketika agent memiliki lebih banyak informasi (full information) daripada principal, sehingga menyebabkan terjadinya asimetry information. Semakin banyak informasi yang dimiliki dapat mendorong manajer bertindak untuk keuntungan sendiri. Dengan sedikit informasi yang dimiliki prinsipal/pemilik modal, akan sulit memonitor perilaku manajemen. Akibatnya, manajemen perusahaan dapat menerapkan kebijakan tertentu tanpa sepengetahuan prinsipal/pemilik modal. Di samping itu manjemen bertindak tidak untuk kepentingan principal namun untuk kepentingan sendiri. ${ }^{14}$

Konflik dapat juga muncul antara manajemen dan pemegang saham, karena kepentingan manajemen dan pemegang saham sering kali bertentangan. Hal ini dikarenakan manajemen mengutamakan kepentingan pribadi individu, sedangkan pemegang saham tidak menyukai kepentingan pribadi manajemen. Pengeluaran ini meningkatkan biaya perusahaan dan menyebabkan penurunan laba dan dividen perusahaan.

\footnotetext{
${ }^{13}$ Ibid., hal. 58

${ }^{14}$ Ibid., hal. 60.
} 
Menurut Jensen dalam Afridian Wirahadi Ahmad,15 masalah keagenan dapat dilihat dari beberapa kriteria, seperti penggunaan arus kas bebas (free cash flow) pada kegiatan yang kurang profitable, meningkatnya kekuatan manajer untuk berinvestasi secara berlebihan, konsumsi yang berlebihan, atau perbedaan pandangan investor dan manajer terhadap investasi. Investor memilih risiko tinggi untuk menghasilkan imbal hasil yang besar, Manajer, di sisi lain, memilih risiko rendah untuk mempertahankan posisinya di perusahaan.

Investor menunjuk manajer untuk mengoperasikan perusahaan, yang akan menimbulkan perbedaan kepentingan antara manajer dan investor. Perbedaan dimungkinkan terjadi karena pengambil keputusan tidak menanggung risiko dari kekeliruan dalam keputusan investasi, atau manajer gagal menambah nilai bagi perusahaan. sehingga manajer/manajemen cenderung mengambil keputusan yang kurang optimal.

\section{Hubungan Keagenan Dalam Pembiayaan Mudharabah}

Secara umum kegiatan penyaluran dana pada nasabah yang dikeluarkan oleh bank syariah terbagi menjadi 3 (tiga) prinsip dalam penyalurannya, antara lain: pertama, pembiayaan prinsip jual beli yaitu murabahah, salam, dan istishna', kedua, pembiayaan meggunakan prinsip sewa yaitu ijarah, dan ketiga, pembiayaan menggunakan prinsip bagi hasil yaitu mudharabah dan musyarakah. ${ }^{16}$

Berdasarkan ketiga prinsip pembiayaan tersebut diatas, yang menjadi produk unggulan bank syariah yaitu produk pembiayaan

\footnotetext{
${ }^{15}$ Afridian Wirahadi Ahmad, Yossi Septriani, Konflik Keagenan: Tinjauan Teoritis dan Cara Menguranginya, dalam Jurnal Akuntansi \& Manajemen Vol 3 No.2 Desember 20081SSN 1858-3687 hal 48.

${ }^{16}$ Heri Sudarsono, Bank dan Lembaga Keuangan Syariah: Deskripsi dan Ilustrasi, (Yogyakrta: Ekonsia, 2007), 56.
} 
yang berdasarkan prinsip bagi hasil, yaitu pembiayaan mudharabah. ${ }^{17}$

Pembiayaan mudharabah merupakan pembiayaan seluruh kebutuhan modal pada suatu usaha produktif yang telah disepakati bersama antara shahib maal dan mudharib. Hasil usaha yang didapat dari pengelolaan usaha produktif tersebut dibagikan kepada bank syariah, sebagai pemilik dana (shahib maal) dengan pengelola usaha (mudharib) berdasarkan kesepakatan.

Selain itu, pembiayaan mudharabah juga dikenal dengan pembiayaan yang berbasis keuntungan dan kerugian. Dimana terdapat kesepakatan antara pemilik dana (shahib maal) dan pengelola dana (mudharib) untuk menanggung keuntungan dan kerugian. ${ }^{18}$

Pada kerangka teoritis keagenan, kontrak mudharabah, yaitu rabbul maal adalah pemilik perusahaan (principal) yang menyediakan seluruh dana awal yang dibutuhkan, sementara mudharib (pengelola) adalah agent yang memiliki kewenangan pengambilan kebijakan, hubungan kerjasama antara rabbul maal dan mudharib tersebut didasari dengan asas kepercayaan. ${ }^{19}$

Pada kontrak mudharabah masalah prinsipal dan agen muncul saat kepentingan mudharib bertentangan dengan kepentingan pemilik dana. Dimana mudharib mengabaikan kontrak yang terjadi antara kedua belah pihak.

10. Potensi Risiko Dalam Pembiayaan Mudharabah Ditinjau Dari Hubungan Keagenan

Seperti yang dijelaskan di atas mudarabah merupakan suatu bentuk perjanjian kerjasama principal/shahibul maal, dengan

\footnotetext{
${ }^{17}$ Adiwarman A. Karim, Ekonomi Islam Suatu Kajian Kontemporer, (Jakarta: Gema Insani, 2001), 83.

${ }^{18}$ Wirdyaningsih, Bank dan Asuransi dalam Islam di Indonesia, (Jakarta: Kencana, 2005), 122.

${ }^{19}$ Asfi Manzilati, Kesepakatan Kelembagaan Kontrak Mudharabah Dalam Kerangka Teori Keagenan, dalam Jurnal Keuangan Dan Perbankan, Vol 15, No. 2, Mei 2001, hal. 284.
} 
agent/mudharib dan keuntungan dibagi antara keduanya. Pada kontrak mudharabah, kepemilikan usaha merupakan kepunyaan bersama antara pemodal dengan pelaksana. Tetapi hak kepemilikan modal mudharabah senantiasa jadi kepunyaan principal/shahibul maal, keuntungan yang dihasilkan oleh usaha syarikat mudharabah kepunyaan bersama serta pembagian keuntungan mereka munurut nisbah untuk hasil yang sudah disepakati bersama.

Kontrak mudharabah pada bank syari'ah, suatu kontrak yang berpeluang besar terjadinya imperfect information, sehingga menyebabkan asymmetric information. Ketidakseimbangan informasi yang dimiliki kedua belah pihak pada pembiayaan mudharabah berpotensi menimbulkan risiko terutama bagi pihak principal dalam hal ini pihak bank syariah, yang menyebabkan terjadinya kerugian dan memberbesar non perfoming financing (pembiayaan bermasalah) bagi bank.

Selain itu, Algoud \& Lewis dalam Asfi Manzilati menyatakan bahwa salah satu potensi risiko dalam kontrak mudharabah disebabkan oleh masalah keagenan, pertama bersumber dari tidak adanya syarat koleteral sehingga menimbulkan permasalahan "adverse selection". Kedua, kontrak mudharabah cenderung menimbulkan moral hazard karena manajer tidak mampu bertindak sesuai dengan kebutuhan bisnis yang diharapkan oleh bank. Disamping itu, bank tidak dapat memberi batasan manajer terkait kekuatan usahanya. Ketiga, bank membayar seluruh biaya perusahaan, sehingga kontrak ini memberikan insentif bagi manajer untuk membayar lebih dari yang diperlukan.

Beberapa hal lain yang berhubungan dengan masalah keagenan dalam kontrak mudharabah, diantaranya ketidakpastian yang besar (great uncertainty) bagi perbankan. Ketidakpastian ini disebabkan oleh 
return bank yang sepenuhnya tergantung pada keputusan investasi agen. Kemudian terkait dengan kekuasaan menentukan arah keputusan (decision). Kontrak mudharabah juga merepresentasikan suatu diskresi, sejak agen mengambil alih kendali bisnis dan memiliki kekuatan untuk membuat keputusan investasi. ${ }^{20}$

\section{Kesimpulan}

Pembiayaan mudharabah adalah pembiayaan seluruh kebutuhan dana untuk usaha produktif yang disepakati bersama antara shahib maal dan mudharib, salah satu permasalahan pada pembiayaan mudharabah adalah masalah keagenan antara shahib al mal/principal dan mudharib/agent yang berpotensi menimbulkan risiko terutama bagi perbankan syari'ah.

\section{DAFTAR PUSTAKA}

Ahmad Wirahadi Afridian, Yossi Septriani, Konflik Keagenan: Tinjauan Teoritis dan Cara Menguranginya, dalam Jurnal Akuntansi \& Manajemen Vol 3 No.2 Desember 2008.

Berbagai pendapat ulama ini disarikan dari tulisan Muhammad, Kontruksi Mudharabah dalam Bisnis Syari'ah, Yogyakarta: BPEE, 2005.

Barnas Benny, Teori Keagenan Dan Manajemen Laba, Jurnal Ekonomi, Keuangan, Perbankan dan Akuntansi, Vol. 1, No. 1, Mei 2009.

Departemen Agama RI, Al-Qur aan dan Terjemahnya, Jakarta : Yayasan Penyelenggara Penterjemah dan Pentafsir Al-Quraan, 1979

Imaniyati Sri Neni, Pengantar Hukum Perbankan Indonesia, Cetakan Pertama, Bandung: Refika Aditama, 2010, dalam Evita Isretno, Pembiayaan Mudharabah Dalam Sistem Perbankan Syari'ah, Jakarta: Cintya Press, 2011.

Isretno Evita, Pembiayaan Mudharabah Dalam Sistem Perbankan Syari'ah, Jakarta: Cintya Press, 2011.

\footnotetext{
${ }^{20}$ Ibid., hal 286.
} 
Jurnal Keuangan dan Perbankan, Vol. 13 No. 3 September 2009, hal 506-517, terakreditasi SK. No. 16/DIKTI/Kep/2007.

Karim, A. Adiwarman, Ekonomi Islam Suatu Kajian Kontemporer, Jakarta: Gema Insani, 2001.

Bank Islam: Analisis Figh dan Keuangan, PT. Raja Grafindo Persada Jakarta, 2008.

Kurniawan Ilyas Oki, Hubungan Pelaksanaan Pembiayaan (Bagi Hasil) Mudharabah Dan Musyarakah Beserta Risikonya Dengan Eksistensi Pt. Bank Syariah Mandiri., 2012. Skripsi Universitas Pembangunan Nasional “VETERAN” Jawa Timur.

Kusumo Nur Azhari, Strategi Meningkatkan Share Pembiayaan Mudharabah Pada Perbankan Syari'ah Di Indonesia (SupplyDemand-Support Strategi). Skripsi Universitas Islam Sunan Kalijaga Yoyakarta, 2012.

Maemunah Siti, Kesiapan Mudharib Dalam Menerima Risiko Usaha Pada Pembiayaan Mudharabah (Kasus Pada Baituttamwil Tamzis Kotagede Yogyakarta). Skripsi Universitas Islam Sunan Kalijaga Yogayakarta, 2007.

Maharani Nur Satia, Menyibak Agency Problem Pada Kontrak Mudharabah dan Alternatif Solusi, dalam Jurnal Keuangan dan Perbankan, Vol. 12, No. 3 September 2008.

Manzilati Asfi, Kesepakatan Kelembagaan Kontrak Mudharabah Dalam Kerangka Teori Keagenan, dalam Jurnal Keuangan Dan Perbankan, Vol 15, No. 2, Mei 2001.

Muhammad, Kontruksi Mudharabah Dalam Bisnis Syari'ah, (Mudharabah Dalam Wacana Fiqih Dan Praktik Ekonomi Modern), Yogyakarta: BPEE, edisi pertama, 2005.

Manajemen Pembiayaan Bank Syari'ah, Yogyakarta: UPN AMP YKPN, 2005.

Atribut proyek Dan Mudharib Dalam Pembiayaan Mudharabah Pada Bank Syari'ah Di Indonesia, dalam Jurnal Ekonomi Dan Bisnis Indonesia, vol. 21, no. 3, 2006. 
Manajemen Pembiayaan Mudharabah Di Bank Syari'ah, Strategi Memaksimalkan Return dan Meminimalkan Resiko Pembiayaan Di Bank Syari'ah Sebagai Akibat Masalah Agency, Jakarta: Rajawali, 2008.

Nurhasanah Ayu, Pelaksanaan Perjanjian Pembiayaan Dengan Prinsip Bagi Hasil (al-Mudharabah) Pada Bank Syari' ah Mandiri Pontianak, Tesis Universitas Diponegoro Semarang.

Nursidik, Akad Mudharabah Pada Perbankan Syari'ah, Hakim Pada Pengadilan Agama Kajen, Artikel.

Rahmawati Naili, Analisis Pembiayaan Mudharabah ( studi Kasus di Bank Muammalat Indonesia Cabang Yogyakarta), 2005, Tesis Universitas Islam Sunan Kalijaga Yogyakarta.

Rahmawati, Yacob Suparno, Nurul Qomariyah, Pengaruh Asimetri Informasi Terhadap Praktik Manajemen Laba Pada Perusahaan Perbankan Publik Yang Terdaftar Di Bursa Efek Jakarta, dalam Simposium Nasional Akuntansi 9 Padang, 2006.

Rastono, Penerapan Prinsip Bagi Hasil Dalam Pembiayaan Terhadap Nasabah Bank Syariah, Tesis Universitas DIPonegoro Semarang, 2008.

Salam Bastian Adi, Kedudukan Perbankan Islam dalam Tata Hukum Perbankan Indonesia, Jurnal Penelitian Hukum, Bengkulu Edisi X Januari, 2000.

Sani Israil, "Pelaksanaan Pembiayaan Berdasarkan Prinsip Bagi Hasil (Mudharabah) Pada Baitul Mal Wa Tamwil (BMT) Agam Madani Nagari Sungai Pua Kabupaten Agam", Skripsi Universitas Andalas Padang, 2011.

Sudarsono Heri, Bank dan Lembaga Keuangan Syariah: Deskripsi dan Ilustrasi, Yogyakrta: Ekonsia, 2007.

Undang-undang No. 10 Tahun 1998 Pasal 1 Angka 3, Himpunan Undang-undang Perbankan Republik Indonesia, (Jakarta: Asa Mandiri, 2008).

Wirdyaningsih, Bank dan Asuransi dalam Islam di Indonesia, Jakarta: Kencana, 2005.

Wiroso, Produk Perbankan Syari'ah, Jakarta: LPEE Usakti, 2009 
Potensi Risiko Pembiayaan Mudharabah ...

Yulianti Timorita Rahmani, Manajemen Risiko Perbankan Syari'ah, dalam Jurnal Ekonomi Islam La_Riba, Vol. III, No. 2, Desember 2009.

Yushita Novi Amanita, Earnings Management Dalam Hubungan Keagenan, Jurnal Pendidikan Akuntansi Indonesia Vol. VIII. No. 1 Tahun 2010.

Zharfan Refaat, “Optimalisasi Skema Bagi Hasil Sebagai Solusi Permasalahan Principal-Agent Dalam Pembiayaan Mudharabah Pada PT. Bank Bni Syariah Cabang Makassar", Skripsi Universitas Hasanuddin Makassar, 2012. 